\title{
Lead Structures for Applications in Photodynamic Therapy. 5. Synthesis and Biological Evaluation of Water Soluble Phosphorus(V) 5,10,15,20-Tetraalkylporphyrins for PDT
}

\author{
Aoife A. Ryan a, Mothi M. Ebrahim a, ${ }^{*}$ Rosine Petidemange ${ }^{a}$, \\ Gisela M. Vaz b, Edyta Paszko b, Natalia N. Sergeeva b', \\ Mathias O. Senge Dr. rer. nat., FTCD ${ }^{a, b,{ }^{*}}$
}

a School of Chemistry, SFI Tetrapyrrole Laboratory, Trinity Biomedical Sciences Institute, 152-160 Pearse Street, Trinity College Dublin, The University of Dublin, Dublin 2, Ireland

b Medicinal Chemistry, Institute of Molecular Medicine, Trinity Centre for Health Sciences, Trinity College Dublin, St James's Hospital, Dublin 8, Ireland

${ }^{*}$ Corresponding author at: School of Chemistry, SFI Tetrapyrrole Laboratory, Trinity College Dublin, Dublin 2, Ireland

E-mail address: sengem@tcd.ie (M.O. Senge).

KEYWORDS

Photodynamic therapy; Photosensitizers; Phosphorous; Porphyrins; Cancer; Esophageal cancer

\section{Summary}

Improved photosensitizers for use in photomedicine must possess good water-solubility and optimal photophysical properties. Phosphorus(V) porphyrins fulfill these criteria and are a class of porphyrins with significant potential applications in phototherapy. Five phosphorus $(\mathrm{V})$ porphyrins bearing alkyl substituents have been synthesized. Reasonable to good yields were obtained for all $P(V)$ insertions and all compounds underwent biological evaluation for their PDT activity on two esophageal cancer cell lines, OE33 and SKGT-4. Their cellular uptake was investigated using a high content screening method. Notably, three compounds displayed good uptake and using the MTS cell proliferation assay, two were shown to have photocytotoxicity comparable to $m$ THPC (Temoporfin $®$ ) with $\mathrm{IC}_{50}$ values of 6.5 and $5.5 \mu \mathrm{M}$. 


\section{Introduction}

Photodynamic therapy (PDT) is the most promising clinical application of porphyrins for cancer therapy and indication $[1,2,3]$. The method relies on the selective accumulation of a photosensitizer in target tissue where it can be activated with light to produce toxic singlet oxygen resulting in, e.g., tumor necrosis [4,5]. However, present PDT drugs have significant draw backs such as slow tissue clearance, low solubility, inefficient targeting, patient photosensitivity, pain, and high costs [6]. Thus, current research targets new photosensitizers with optimized photophysical and pharmacological properties [7]. This often requires significant chemical manipulation [6] (more synthetic steps) or complex formulation strategies [9,10] (liposomes, nanomaterials) whereby the biocompatibility is somewhat unclear. Current bioconjugate research developments $[11,12,13,14]$ (antibodies, sugars, steroids, etc.) involve expensive and complicated methodology, whilst state-of-the-art drugs such as Temoporfin are undergoing further developments [15,16], mostly in terms of nanoformulations to increase their efficacy and application potential or in terms of new uses, e.g., antimicrobial action [17]. Thus, PDT development is becoming ever more specialized.

More practical advances in this area require simple approaches that can be applied to a wide variety of cases and applications. Here, we present the use of $P(V)$ porphyrin complexes which offer such a possibility, as they allow not only the preparation of new drug candidates but simple improvements of existing drugs through $\mathrm{P}(\mathrm{V})$ complexation, i.e., water solubility [18], better uptake and potentially less side effects. $\mathrm{P}(\mathrm{V})$ porphyrin complexes are known but their exploitation in terms of PDT has been limited thus far $[18,19,20,21,22,23,24,25]$. We found that through $P(V)$ complexation of simple meso tetrasubstituted porphyrins both the water solubility and the in vitro cytotoxicity of the photosensitizer can be drastically improved with respect to the non-complexed form.

\section{Materials and Methods}

\section{General procedure for cell cultures and cell proliferation assay (MTS)}

Two different cell lines were used in the biological studies: the human adenocarcinoma cell line SKGT-4, and the human adenocarcinoma cell line OE33 derived from Barrett's esophagus. The cells were routinely cultured antibiotic free in RPMI 1640 (Hyclone, USA) with 10\% inactivated fetal bovine serum (Hyclone, USA) and $1 \%$ Penicillin/Streptomycin (Hyclone, USA). These cultures were grown in sterile filtered top cell culture flasks (Nunc, Denmark). Cultures were split 1:8 when $70-80 \%$ confluency was reached. Cell recovery was achieved using Trypsin $0.25 \%$ with $0.1 \%$ EDTA (Hyclone, USA) and kept at $37{ }^{\circ} \mathrm{C}$ and $5 \% \mathrm{CO}_{2}$ in a humidified atmosphere. Culture medium was changed every 3 to 4 days until confluency was obtained. Cell lines were seeded at a concentration of $1.5 \times 10^{4}$ cells $/ \mathrm{mL}$ into sterile 96 -well plates, left to attach overnight in an incubator $\left(37{ }^{\circ} \mathrm{C}, 5 \% \mathrm{CO}_{2}\right)$ and treated. To previously prepared 96-well assay plates containing cells in $100 \mu \mathrm{L}$ of culture medium, test 
compounds, including $m$ THPC (Temoporfin $\AA$ ), at different concentrations $(10-50 \mu \mathrm{M})$ and appropriate controls were added (untreated cells were used as control). After incubation for $24 \mathrm{~h}$ the medium was removed and changed for fresh one, dark controls were left in the dark for next $24 \mathrm{~h}$. To assess the phototoxicity [26], the rest of the plates were illuminated for 2 min using Luxeon High Power LEDs (LXHL-BW03) as light sources emitting white light with a total fluence rate of $1.7 \mathrm{~mW} \mathrm{~cm}^{-2}$ and incubated for 24 h. $20 \mu \mathrm{L}$ of the MTS dye solution was added to each well of the dark controls and illuminated plates and these were incubated for $3 \mathrm{~h}$ and the absorbance was recorded at $470 \mathrm{~nm}$ using a 96-well plate reader and imaging technique (InCell analyzer 1000 instrument, GE Healthcare).

\section{Biological Evaluation}

Intracellular screening for the compounds 3a-3e was carried out in OE33 and SKGT-4 cell lines. Stock solutions of the $P(V)$ porphyrins $(0.5 \mathrm{mM})$ were prepared in ethanol:propylene glycol $(60: 40 \mathrm{v} / \mathrm{v})$. Cell lines were seeded at a concentration of 3000 cells per $\mathrm{mL}$ into sterile 96-well plates leaving them for $24 \mathrm{~h}$ to attach. For imaging experiments, the cell culture medium was removed, replaced with freshly prepared solutions of the porphyrins $3 a-3 e$ of various concentrations $(10-50 \mu \mathrm{M})$ in the medium and incubated at $37{ }^{\circ} \mathrm{C}$ under $5 \% \mathrm{CO}_{2}$ for $24 \mathrm{~h}$. After that the medium was removed and fixed with $4 \%$ PFA in medium and then washed with PBS. The fixed adenocarcinoma cells were then co-stained using nuclear dye Hoechst $33342(1 \mu \mathrm{g} / \mathrm{mL})$ and the bicyclic peptide DY-490 Phalloidin (1:500 in $100 \mu \mathrm{L}$ ) as cytoskeleton stain (F-actin). Fluorescent images were collected and analyzed by high content screening using InCell 1000 and in vitro images were taken at different concentrations. These images were collected using three independent channels for Hoechst, Phalloidin and the compounds $3 a-3 e$ with excitation/emission filters of $345 / 435 \mathrm{~nm}$ (blue), $475 / 535 \mathrm{~nm}$ (green) and 620/700 nm (red), respectively.

\section{Chemical Synthesis}

General procedure for the synthesis of compounds 3a-e: A dry $50 \mathrm{~mL}$ Schlenk flask was charged with free base porphyrin (1 eq.) under Ar atmosphere. To this, dry dichloromethane $5 \mathrm{~mL}$ and 2,6-lutidine (115 equiv.) were added and stirred for 5 mins. A $2 \mathrm{M}$ solution of $\mathrm{PCl}_{3}$ in dichloromethane (15 eq.) was added very slowly dropwise. The mixture was left to stir for $24 \mathrm{~h}$ (TLC control) at rt. Then the reaction was quenched by careful addition of water $(2 \mathrm{~mL})$ under ice cold conditions. Additional $20 \mathrm{~mL}$ water was added followed by extraction with dichloromethane $(3 \times 200 \mathrm{~mL})$. The combined organic layer was washed with water and the volatiles were removed in vacuo. The crude product containing a mixture of chloro and hydroxo axial ligands was redissolved in acetone $(100 \mathrm{~mL})$. A $5 \mathrm{~mL}$ aqueous $\mathrm{AgNO}_{3}$ solution $(0.75 \mathrm{~g}, 4.50 \mathrm{mmol}, 25$ eq.) was added and the mixture stirred for $2 \mathrm{~h}$ at $\mathrm{rt}$. After complete removal of acetone, the residue was extracted with dichloromethane $(3 \times 200 \mathrm{~mL})$, washed with water, dried over $\mathrm{Na}_{2} \mathrm{SO}_{4}$ and the solvent removed. The crude product was purified by silica column chromatography. Elution with dichloromethane removed a red band containing small amount of unreacted porphyrin and other unidentified impurities. The desired product 
was then eluted as a purple band using 5-20\% acetone/dichloromethane (v/v). The sticky product obtained was triturated with hexanes to afford a purple solid.

Dihydroxo(5,10,15,20-tetra(n-butyl)porphyrinato)phosphorus(V) hydroxide, 3a: Compound $3 \mathbf{a}$ was obtained following the general procedure using $1 \mathrm{a}(0.1 \mathrm{~g}, 0.18$ mmol), 2,6-lutidine $(2.5 \mathrm{~mL}, 21.46 \mathrm{mmol})$ and $\mathrm{PCl}_{3}(2 \mathrm{M}$ in dichloromethane) $(1.4 \mathrm{~mL}$, $2.80 \mathrm{mmol}$ ), yield: $27 \mathrm{mg}(0.043 \mathrm{mmol}, 24 \%)$; $\mathrm{Mp}>300{ }^{\circ} \mathrm{C} ; R_{f}$ (acetone, silica) $0.25 ;{ }^{1} \mathrm{H}$ NMR $\left(400 \mathrm{MHz}, \mathrm{CDCl}_{3}\right): \delta=9.25(\mathrm{br} \mathrm{s}, 8 \mathrm{H}, \beta-H), 4.33\left(\mathrm{t}, J=8.0 \mathrm{~Hz}, 8 \mathrm{H}, \mathrm{CH}_{2}\right) 1.91$ (quintet, $J=8.0 \mathrm{~Hz}, 8 \mathrm{H}, \mathrm{CH}_{2}$ ), 1.14 (sextet, $J=8.0 \mathrm{~Hz}, 8 \mathrm{H}, \mathrm{CH}_{2}$ ), 0.78 (t, $J=8.0 \mathrm{~Hz}$, $\left.12 \mathrm{H}, \mathrm{CH}_{3}\right) \mathrm{ppm} ;{ }^{31} \mathrm{P}\left\{{ }^{1} \mathrm{H}\right\}$ NMR (162 $\left.\mathrm{MHz}, \mathrm{CDCl}_{3}\right): \delta=195.6$ (s) ppm; ATR-FTIR (thin film, $\left.\mathrm{cm}^{-1}\right): v=3093,2951,2929,2865,1651,1626,1516,1439,1373,1311,1231$, 1159, 1102, 1083, 1069, 1032, 960 (VP-O), 892, 825, 792, 778, 747, 710, $691 \mathrm{~cm}^{-1}$; UV/vis (THF): $\lambda_{\max }(\log \varepsilon)=426$ (5.27), 561 (3.84), 605 (3.48) nm; HRMS (MALDI-TOF ${ }^{+}$) $\left[\mathrm{C}_{36} \mathrm{H}_{46} \mathrm{~N}_{4} \mathrm{O}_{2} \mathrm{P}_{1}\right]$ : calcd. [M-OH] $]^{+}$597.3358, found 597.3375.

Dihydroxo(5,10,15,20-tetrahexylporphyrinato)phosphorus $(V)$ hydroxide, $\quad 3 \mathbf{b}$ : Compound $\mathbf{3 b}$ was obtained following the general procedure using $\mathbf{1 b}(0.1 \mathrm{~g}, 0.18$ $\mathrm{mmol}), 2$,6-lutidine $(2.5 \mathrm{~mL}, 21.46 \mathrm{mmol})$ and $\mathrm{PCl}_{3}(2 \mathrm{M}$ in dichloromethane $)(1.4 \mathrm{~mL}$, $2.80 \mathrm{mmol}$ ), yield: $26 \mathrm{mg}(0.035 \mathrm{mmol}, 20 \%), \mathrm{Mp}>300{ }^{\circ} \mathrm{C} ; R_{f}$ (acetone, silica) $0.40 ;{ }^{1} \mathrm{H}$ NMR $\left(400 \mathrm{MHz}, \mathrm{CDCl}_{3}\right): \delta=9.31(\mathrm{br} \mathrm{s}, 8 \mathrm{H}, \beta-\mathrm{H}), 4.37\left(\mathrm{t}, J=8.0 \mathrm{~Hz}, 8 \mathrm{H}, \mathrm{CH}_{2}\right), 3.71-$ $3.64\left(\mathrm{~m}, 8 \mathrm{H}, \mathrm{CH}_{2}\right.$ ), 3.38 (dd, $\mathrm{J}=8.0 \mathrm{~Hz}, 8 \mathrm{H}, \mathrm{CH}_{2}$ ), 3.17 (dd, $J=8.0 \mathrm{~Hz}, 8 \mathrm{H}, \mathrm{CH}_{2}$ ), 1.96$1.86\left(\mathrm{~m}, 8 \mathrm{H}, \mathrm{CH}_{2}\right), 0.75\left(\mathrm{t}, J=4.0 \mathrm{~Hz}, 12 \mathrm{H}, \mathrm{CH}_{3}\right) \mathrm{ppm} ;{ }^{31} \mathrm{P}\left\{{ }^{1} \mathrm{H}\right\} \mathrm{NMR}\left(162 \mathrm{MHz}, \mathrm{CDCl}_{3}\right)$ : $\delta=196.0$ (s) ppm; ATR-FTIR (thin film, $\mathrm{cm}^{-1}$ ): $v=3098,2924,2855,1718,1517,1458$, $1376,1313,1232,1154,1112,1074,1037,960,890,781,706 \mathrm{~cm}^{-1}$; UV/vis (THF): $\lambda_{\max }$ $(\log \varepsilon)=426$ (5.27), 561 (3.86), 605 (3.52) nm; HRMS (MALDI-TOF ${ }^{+}$) $\left[\mathrm{C}_{44} \mathrm{H}_{62} \mathrm{~N}_{4} \mathrm{O}_{2} \mathrm{P}_{1}\right]$ : calcd $[\mathrm{M}-\mathrm{OH}]^{+} 709.4610$, found 709.4613 .

Dihydroxo(5,10,15, 20-tetrakis(2-methylpropyl)porphyrinato)phosphorus(V)

hydroxide, 3c: Compound 3c was obtained following the general procedure using 1c $(0.1 \mathrm{~g}, 0.18 \mathrm{mmol}), 2,6$-lutidine $(2.5 \mathrm{~mL}, 21.46 \mathrm{mmol})$ and $\mathrm{PCl}_{3}(2 \mathrm{M}$ in dichloromethane) $(1.4 \mathrm{~mL}, 2.80 \mathrm{mmol})$, yield: $53 \mathrm{mg}(0.088 \mathrm{mmol}, 49 \%), \mathrm{Mp}>300{ }^{\circ} \mathrm{C} ; R_{f}$ (acetone, silica) $0.45 ;{ }^{1} \mathrm{H}$ NMR $\left(400 \mathrm{MHz}, \mathrm{CDCl}_{3}\right): \delta=9.30(\mathrm{br} \mathrm{s}, 8 \mathrm{H}, \beta-H), 4.38\left(\mathrm{~d}, J=8.0 \mathrm{~Hz}, 8 \mathrm{H}, \mathrm{CH}_{2}\right)$, 1.89-1.83 (m, 4H, CH), $0.48\left(\mathrm{~s}, 12 \mathrm{H}, \mathrm{CH}_{3}\right), 0.46\left(\mathrm{~s}, 12 \mathrm{H}, \mathrm{CH}_{3}\right) \mathrm{ppm} ;{ }^{31} \mathrm{P}\left\{{ }^{1} \mathrm{H}\right\} \mathrm{NMR}(162$ $\mathrm{MHz}, \mathrm{CDCl}_{3}$ ): $\delta=195.8$ (s); ATR-FTIR (thin film, $\mathrm{cm}^{-1}$ ): $v=3101,2955,2926,2867$, $1691,1510,1464,1365,1321,1228,1167,1120,1078,1036,970,882,820,781,707$ $\mathrm{cm}^{-1}$; UV/vis (THF): $\lambda_{\max }(\log \varepsilon)=426$ (5.28), 563 (3.86), 605 (3.58) nm; HRMS (MALDITOF $^{+}$) $\left[\mathrm{C}_{36} \mathrm{H}_{46} \mathrm{~N}_{4} \mathrm{O}_{2} \mathrm{P}_{1}\right]$ : calcd [M-OH] ${ }^{+}$597.3358, found 597.3367.

\section{Dihydroxo(5,10,15,20-tetrakis(1-methylpropyl)porphyrinato)phosphorus(V)}

hydroxide, 3d: Compound 3d was obtained following the general procedure using 1d $(0.1 \mathrm{~g}, 0.18 \mathrm{mmol}), 2,6$-lutidine $(2.5 \mathrm{~mL}, 21.46 \mathrm{mmol})$ and $\mathrm{PCl}_{3}(2 \mathrm{M}$ in dichloromethane) $(1.4 \mathrm{~mL}, 2.80 \mathrm{mmol})$, yield: $42 \mathrm{mg}(0.070 \mathrm{mmol}, 39 \%) . \mathrm{Mp}>300{ }^{\circ} \mathrm{C} ; R_{f}$ (acetone, silica) 0.47; ${ }^{1} \mathrm{H}$ NMR $\left(400 \mathrm{MHz}, \mathrm{CDCl}_{3}\right): \delta=9.23(\mathrm{br} \mathrm{s}, 8 \mathrm{H}, \beta-H)$, 4.18-4.09 (m, 4H, CH), 2.44$2.33\left(\mathrm{~m}, 8 \mathrm{H}, \mathrm{CH}_{2}\right), 2.29-2.25\left(\mathrm{~m}, 12 \mathrm{H}, \mathrm{CH}_{3}\right), 0.68-0.62\left(\mathrm{~m}, 12 \mathrm{H}, \mathrm{CH}_{3}\right) \mathrm{ppm} ;{ }^{31} \mathrm{P}\left\{{ }^{1} \mathrm{H}\right\}$ NMR (162 MHz, CDCl 3 ): $\delta=198.4$ (s) ppm; ATR-FTIR (thin film, $\mathrm{cm}^{-1}$ ): $v=3134,2961$, 2926, 2871, 1696, 1500, 1457, 1375, 1315, 1228, 1075, 1038, 1002, 879, 824, 782, 714 
$\mathrm{cm}^{-1}$; UV/vis (THF): $\lambda_{\max }(\log \varepsilon)=428$ (5.28), 564 (3.89), 605 (3.52) nm; HRMS (MALDI$\left.\mathrm{TOF}^{+}\right)\left[\mathrm{C}_{36} \mathrm{H}_{46} \mathrm{~N}_{4} \mathrm{O}_{2} \mathrm{P}_{1}\right]$ : calcd $[\mathrm{M}-\mathrm{OH}]^{+}$597.3358, found 597.3355.

Dihydroxo(5,10,15, 20-tetrakis(1-ethylpropyl)porphyrinato)phosphorus(V) hydroxide, 3e: Compound $3 \mathrm{e}$ was obtained following the general procedure using $1 \mathrm{e}$ $(0.1 \mathrm{~g}, 0.15 \mathrm{mmol}), 2,6$-lutidine $(1.8 \mathrm{~mL}, 17.25 \mathrm{mmol})$ and $\mathrm{PCl}_{3}(2 \mathrm{M}$ in dichloromethane) $(1.1 \mathrm{~mL}, 2.31 \mathrm{mmol})$, yield: $61 \mathrm{mg}(0.090 \mathrm{mmol}, 60 \%) ; \mathrm{Mp}>300^{\circ} \mathrm{C} ; R_{f}$ (acetone, silica) 0.45 ; ${ }^{1} \mathrm{H}$ NMR $\left(400 \mathrm{MHz}, \mathrm{CDCl}_{3}\right): \delta=9.27$ (br s, 8H, $\left.\beta-H\right)$, 3.93-3.86 (m, 4H, CH), 2.59$2.48\left(\mathrm{~m}, 16 \mathrm{H}, \mathrm{CH}_{2}\right), 0.77\left(\mathrm{br}, 24 \mathrm{H}, \mathrm{CH}_{3}\right) \mathrm{ppm} ;{ }^{31} \mathrm{P}\left\{{ }^{1} \mathrm{H}\right\} \mathrm{NMR}\left(162 \mathrm{MHz}, \mathrm{CDCl}_{3}\right): \delta=$ 197.7 (s) ppm; ATR-FTIR (thin film, $\mathrm{cm}^{-1}$ ): $v=3223,2962,2931,2871,1695,1500$, 1458, 1376, 1312, 1226, 1084, 1039, 950, 880, 827, 785, 711, $658 \mathrm{~cm}^{-1}$; UV/vis (THF): $\lambda_{\max }(\log \varepsilon)=428$ (5.27), 565 (4.06), 605 (3.88) nm; HRMS (MALDI-TOF ${ }^{+}$) $\left[\mathrm{C}_{40} \mathrm{H}_{54} \mathrm{~N}_{4} \mathrm{O}_{2} \mathrm{P}_{1}\right]$ : calcd [M-OH] ${ }^{+}$653.3984, found 653.3978 .

\section{Results and Discussion}

\section{Synthesis}

Meso aryl and $\beta$-octaethyl $\mathrm{P}(\mathrm{V})$ porphyrins have been prepared before, mostly for coordination studies, redox chemistry investigations, and structural analyses $[19,20,21,22,23,24]$. The procedure we adopted followed that developed for $P(V)$ insertion of $2,3,7,8,12,13,17,18$-octaethylporphyrin derivatives, whereby $\mathrm{PCl}_{3}$ acts as a more effective reagent for insertion over $\mathrm{POCl}_{3}$ due to a lower phosphorus oxidation state $[23,24]$. Our initial studies to prepare $P(V)$ alkylporphyrins gave mixtures of the chloro and hydroxide complexes. Similar results were obtained with other reagents. However, optimization studies revealed that a change of the in situ generated chloro complexes to the hydroxide complexes was possible using aqueous silver nitrate as a halide abstractor.

This allowed for the synthesis of simple $S_{4}$-symmetric $P(V)$ porphyrins $3 a-3 e$ using a two-step method, involving the use of anhydrous dichloromethane under an inert atmosphere, in moderate to good yields of $20-60 \%$ (Scheme 1). Despite the presence of meso alkyl residues these compounds proved to be highly soluble in organic solvents and water and much easier to work with than related meso aryl counterparts. Additionally, the synthetic sequence is a much simpler strategy than that of commercial photosensitizers such as $m$ THPC (Temoporfin $®$ ), whereby multiple steps, harsher conditions and lengthy chromatographys are necessary. In contrast, here, simple $\mathrm{P}(\mathrm{V})$ insertion is obtained using mild conditions in a 2-component 1-step strategy, requiring minimal chromatography.

Figure 1 shows the UV-vis absorption spectra of compound $\mathbf{3 d}$ and that of the known photosensitizer mTHPC. A distinct bathochromic shift in the Soret band absorption of $3 \mathbf{d}$ is observed in comparison to $m$ THPC (428 vs. $415 \mathrm{~nm}$ ). A similar effect is observed in comparison with the uncomplexed form $\mathbf{2 d}$. Whilst $m$ THPC displays a typical chlorin absorption at $651 \mathrm{~nm}(\varepsilon \sim 22000)$, 3d displays a stronger Soret absorption than that of $m \operatorname{THPC}(\varepsilon \sim 196,000$ vs. 146,000). 


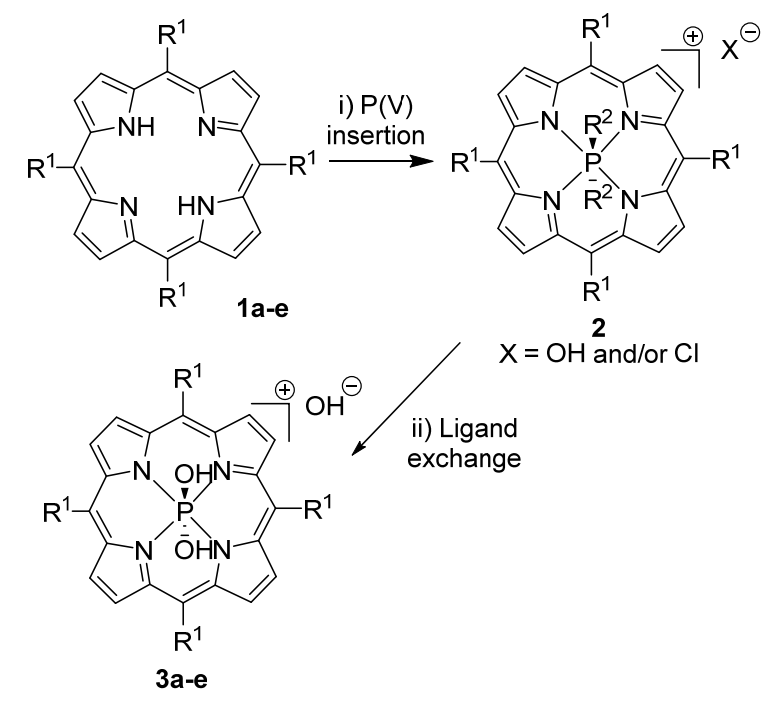

\begin{tabular}{c|ccc}
\hline Entry & $\boldsymbol{R}^{1}$ & Compound & Yield \% \\
\hline 1 & n-butyl & 3a & 24 \\
2 & n-hexyl & 3b & 20 \\
3 & 2-methylpropyl & 3c & 49 \\
4 & 1-methylpropyl & 3d & 39 \\
5 & 1-ethylpropyl & 3e & 60 \\
\hline
\end{tabular}

Scheme 1: Synthesis of $\mathrm{P}(\mathrm{V})$ porphyrins. Reagents and conditions: i) $P(V)$ insertion: $\mathrm{PCl}_{3}, 2$,6-lutidine, DCM, rt, argon; ii) Ligand exchange: aq. $\mathrm{AgNO}_{3}$, acetone.

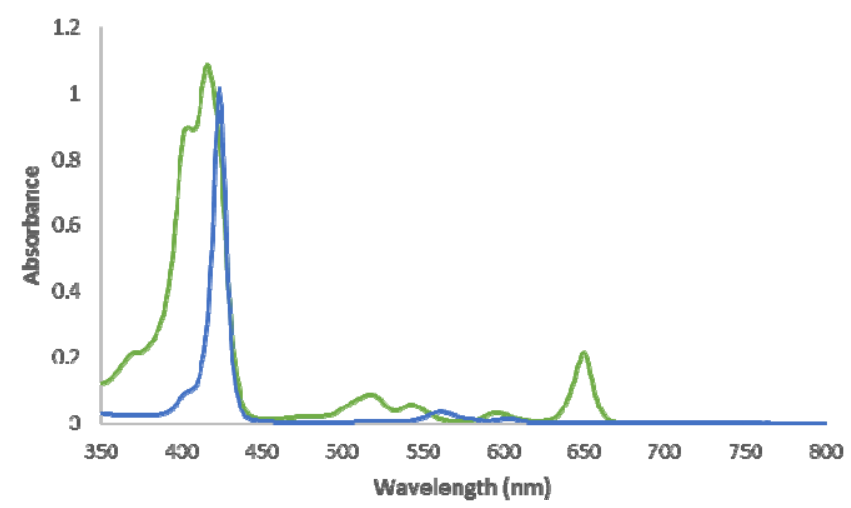

Figure 1: UV-vis absorption spectra of $\mathbf{3} \mathbf{d}$ (blue) versus $m$ THPC (green) in $\mathrm{MeOH}$. 


\section{In vitro Studies}

All compounds synthesized were screened for PDT activity. Specifically, their photodynamic potential as novel and effective PDT reagents for esophageal cancer treatment [27] was evaluated on human esophageal adenocarcinoma cell lines SKGT-4 and OE33 $[28,29]$. Preliminary investigations show that the water soluble $P(V)$ porphyrin compounds, which are relatively easy to synthesize, can be used as versatile materials in PDT. Imaging analysis using high content screening (HCS) [26] showed that the P(V) porphyrins are readily taken up by SKGT-4 and OE33 cell lines after $24 \mathrm{~h}$ incubation and showed no visible toxicity in the dark. Images obtained by the InCell analyzer are shown in Figure 2 and show the photosensitizer uptake in red, dispersed within the cytoplasm of the cells. Table 1 shows the PDT effect of compounds $\mathbf{3 d}, \mathbf{3 e}$ and $\mathbf{3 a}$ against OE33 and SKGT-4 cancer cell lines. Assessment of (photo)toxicity (toxicity in the dark = cytotoxicity vs. light toxicity = phototoxicity) was performed using cell proliferation assays (MTS) using white light as a light source for our preliminary in vitro screen. Primary results of the three non-specifically designed porphyrins showed that after a post-illumination incubation of $24 \mathrm{~h}$, two compounds exhibit promising phototoxicty and a minimal dark toxicity.

The $\mathrm{IC}_{50}$ after illumination of $\mathbf{3 d}$ was $6.5 \pm 0.01 \mu \mathrm{M}$ and $7.0 \pm 0.01 \mu \mathrm{M}$ in SKGT-4 cells and OE33 cells, respectively. The $\mathrm{IC}_{50}$ in the dark for $3 \mathrm{~d}$ was $42.5 \pm 0.02 \mu \mathrm{M}$ in SKGT-4 cell line and $43.0 \pm 0.02 \mu \mathrm{M}$ in OE33 cell line. Similar results were observed for 3a where $\mathrm{IC}_{50}$ values of $5.5 \pm 0.01 \mu \mathrm{M}$ and $6.0 \pm 0.01 \mu \mathrm{M}$ were observed in SKGT-4 and OE33 cell lines, respectively. However, an enhanced dark toxicity was observed for this compound, whereby $\mathrm{IC}_{50}$ values of $24.5-28.0 \mu \mathrm{M}$ were seen with both cell lines. Compound 3e demonstrated meaningful lower cytotoxicity, with an $\mathrm{IC}_{50}$ of $45 \mu \mathrm{M}$ in SKGT-4 and $48 \mu \mathrm{M}$ in OE33 cell lines after illumination and no significant dark toxicity up to $50 \mu \mathrm{M}$. These results show that PDT activity of $\mathrm{P}(\mathrm{V})$ porphyrins is comparable to the commercially available $m$ THPC. Temoporfin was determined to have an $\mathrm{IC}_{50}$ of approx. $5 \mu \mathrm{M}$ in both SKGT-4 and OE33 cancer cell lines with minimal dark toxicity, via control experiments.

In conclusion, we have synthesized simple, $\mathrm{S}_{4}$ symmetric $\mathrm{P}(\mathrm{V})$ alkylporphyrins which are water soluble and even the chemically simplest symmetric dyes show PDT activity in esophageal cells on par with the contemporary, clinically approved photosensitizer mTHPC (Temoporfin, Foscan®) despite the different localization behavior of water soluble versus non water soluble photosensitizers. The novel photosensitizing agents demonstrate significant toxicity after irradiation with light and minimal dark cytotoxicity, making them potential inexpensive candidates for PDT. Although these compounds have yet to be optimized in terms of enhanced absorption for better light penetration and enhanced target tissue accumulation via the inclusion of bioconjugates, our preliminary studies prove that this " $P(V)$ effect" methodology has the potential to enhance the PDT activity and cellular uptake of even the simplest of tetrapyrrole. It is anticipated that these finding will enable the extension of the studies to the in vivo stage and beyond. Future work will involve localization studies, and singlet oxygen quantum yield determination. Additionally, the antimicrobial PDT activity of compounds $\mathbf{3 a}$ and $\mathbf{3 d}$ will be investigated for their applicability to serve as surface disinfectants. In order to improve uptake and intracellular localization within 
adenocarcinoma cells we will prepare a set of $P(V)$ porphyrins with more unsymmetrically substituted porphyrins. This concept will be used to prepare amphiphilic derivatives (with polar and nonpolar side groups) to improve membrane passage. Our simple and facile method for $\mathrm{P}(\mathrm{V})$ insertion allows the conversion of any other porphyrin free base, including those that have been specifically prepared for PDT e.g. two photon absorbers, conjugated systems (both of which exhibit a red shift in absorption for use with red/near-IR light source irradiation), arrays and bioconjugates. In doing so these macrocyclic systems with already optimized substitution patterns may be further improved through the " $P(V)$ effect", i.e. increased water solubility, increased cytotoxicity and better absorption properties. 

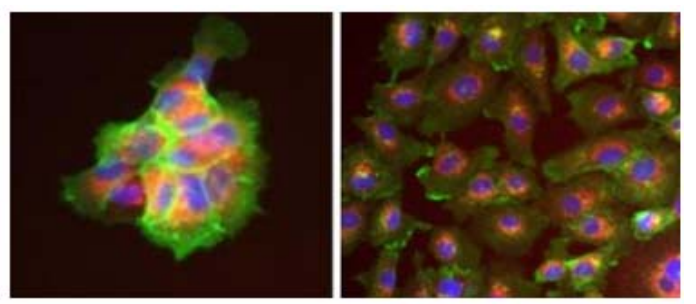

3d
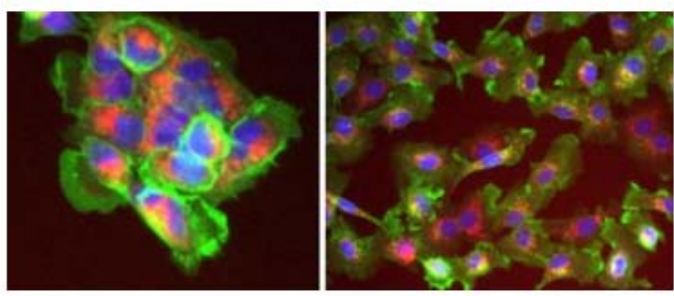

$3 \mathbf{e}$

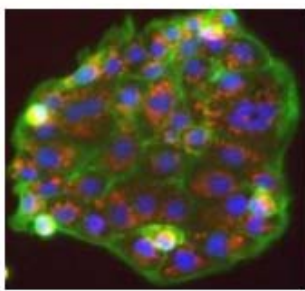

OE33

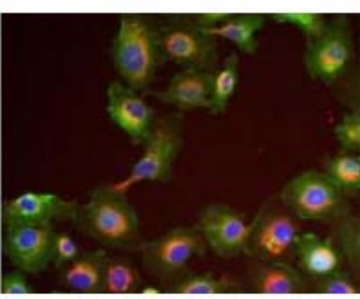

SKGT-4

Figure 2: Images collected from InCell analyzer. Images present OE33 and SKGT-4 cells treated with porphyrins $\mathbf{3 d}, \mathbf{3 e}$ and $\mathbf{3 a}$ after $24 \mathrm{~h}$ incubation. Blue color represents nuclei stained by Hoechst; green color shows F-actin stained by phalloidin; red color represents photosensitizer.

Table 1: PDT effect of porphyrins $\mathbf{3 d}, \mathbf{3 e}$ and $\mathbf{3 a}$ using MTS assay.

\begin{tabular}{|c|c|c|c|c|}
\hline \multirow[b]{2}{*}{ Compound } & \multicolumn{2}{|c|}{ SKGT-4 } & \multicolumn{2}{|c|}{ OE33 } \\
\hline & $\begin{array}{l}I C_{50} \text { light } \\
\mu M \pm S D\end{array}$ & $\begin{array}{l}I_{50} \text { dark } \\
\mu M \pm S D\end{array}$ & $\begin{array}{l}I C_{50} \text { light } \\
\mu M \pm S D\end{array}$ & $\begin{array}{c}I_{50} \text { dark } \\
\mu M \pm S D\end{array}$ \\
\hline $\begin{array}{c}\text { Temoporfin }{ }^{\circledR} \\
\text { (control) }\end{array}$ & $\begin{array}{c}5 \mu \mathrm{M} \\
( \pm 0.01)\end{array}$ & $>50 \mu \mathrm{M}$ & $\begin{array}{c}5.1 \mu \mathrm{M} \\
( \pm 0.013)\end{array}$ & $>50 \mu \mathrm{M}$ \\
\hline $3 d$ & $\begin{array}{c}6.5 \mu \mathrm{M} \\
( \pm 0.011)\end{array}$ & $\begin{array}{l}42.5 \mu \mathrm{M} \\
( \pm 0.022)\end{array}$ & $\begin{array}{c}7 \mu \mathrm{M} \\
( \pm 0.01)\end{array}$ & $\begin{array}{l}43.5 \mu \mathrm{M} \\
( \pm 0.023)\end{array}$ \\
\hline $3 e$ & $\begin{array}{c}45 \mu \mathrm{M} \\
( \pm 0.022)\end{array}$ & $>50 \mu \mathrm{M}$ & $48 \mu \mathrm{M}$ & $>50 \mu \mathrm{M}$ \\
\hline $3 a$ & $\begin{array}{l}5.5 \mu \mathrm{M} \\
( \pm 0.01)\end{array}$ & $\begin{array}{c}28 \mu \mathrm{M} \\
( \pm 0.020)\end{array}$ & $\begin{array}{c}6 \mu \mathrm{M} \\
( \pm 0.014)\end{array}$ & $\begin{array}{l}24.5 \mu \mathrm{M} \\
( \pm 0.016)\end{array}$ \\
\hline
\end{tabular}




\section{Acknowledgments}

This work was supported by grants from Science Foundation Ireland (SFI P.I. 09/IN.1/B2650 and 12/TIDA/B2381) and the Irish Research Council.

\section{References}

[1] Dougherty TJ, Gomer CJ, Henderson BW, Jori G, Kessel, D, Korbelik M, Peng Q. Photodynamic therapy. J Natl Cancer Inst 1998; 90:889-905.

[2] Nyman ES, Hynninen PH. Research advances in the use of tetrapyrrolic photosensitizers for photodynamic therapy $\mathrm{J}$ Photochem Photobiol B:Biol 2004; 73:1-28.

[3] O'Connor AE, Gallagher WM, Byrne AT. Porphyrin and Nonporphyrin Photosensitizers in Oncology: Preclinical and Clinical Advances in Photodynamic Therapy. Photochem Photobiol 2009; 85:1053-1074.

[4] Dougherty TJ. Photodynamic Therapy. Photochem Photobiol 1993; 58:895900.

[5] Bonnett R. Chemical Aspects of Photodynamic Therapy. Gordon \& Breach Science Publ.: Amsterdam, 2000.

[6] Brown SB, Brown EA, Walker I. The present and future role of photodynamic therapy in cancer treatment. Lancet Oncol 2004; 5:497-508.

[7] Ethirajan M, Chen YH, Joshi P, Pandey RK. The role of porphyrin chemistry in tumor imaging and photodynamic therapy. Chem Soc Rev 2011; 40:340362.

[8] Senge MO. Stirring the porphyrin alphabet soup - functionalization reactions for porphyrins. Chem Commun 2011; 47:1943-1960.

[9] Figueira F, Cavaleiro JAS, Tome JPC. Silica nanoparticles functionalized with porphyrins and analogs for biomedical studies. J Porphyrins Phthalocyanines 2011; 15:517-533.

[10] Paszko E, Ehrhardt C, Senge MO, Kelleher DP, Reynolds JV. Nanodrug applications in photodynamic therapy. Photodiagn Photodyn Ther 2011; 8:1429.

[11] Laville I, Figueiredo T, Loock B, Pigaglio S, Maillard P, Grierson DS, Carrez D, Croisy A, Blais J. Synthesis, cellular internalization and photodynamic activity of glucoconjugated derivatives of tri and tetra(metahydroxyphenyl)chlorins. Bioorg Med Chem 2003; 11:1643-1652.

[12] Bryden F, Maruani A, Savoie H, Chudasama V, Smith MEB, Caddick S, Boyle RW. Regioselective and Stoichiometrically Controlled Conjugation of Photodynamic Sensitizers to a HER2 Targeting Antibody Fragment. Bioconj Chem 2014; 25:611-617.

[13] Wang JTW, Giuntini F, Eggleston IM, Bown SG, MacRobert AJ. Photochemical internalisation of a macromolecular protein toxin using a cell penetrating peptide-photosensitiser conjugate. J Control Rel 2012; 157:305313. 
[14] Rogers L, Majer F, Sergeeva NN, Paszko E, Gilmer JF, Senge MO. Synthesis of Foscan ${ }^{\circledR}$ Bile Acid Conjugates for Potential Use in Photodynamic Therapy. Bioorg Med Chem Lett 2013; 23:2495-2499.

[15] Gravier J, Schneider R, Frochot C, Bastogne T, Schmitt F, Didelon J, Guillemin F, Barberi-Heyob M. Improvement of metatetra(hydroxyphenyl)chlorin-like photosensitizer selectivity with folate-based targeted delivery. Synthesis and in vivo delivery studies. J Med Chem 2008; 51:3867-3877.

[16] Senge MO. Senge, M. O. (2012): Lead structures for applications in photodynamic therapy. Part 4. mTHPC - A drug on its way from second to third generation photosensitizer? Photodiagn Photodyn Ther 2012; 9:170179.

[17] Hamblin MR, Hasan T. Photodynamic therapy: a new antimicrobial approach to infectious disease? Photochem Photobiol Sci 2004; 3:436-450.

[18] Matsumoto J, Shinbara T, Tanimura S-i, Matsumoto T, Shiragami T, Yokoi H, Nosaka Y, Okazaki S, Hirakawa K, Yasuda M. Water-soluble phosphorus porphyrins with high activity for visible light-assisted inactivation of Saccharomyces cerevisiae . J Photochem Photobiol A:Chem 2011; 218:178184.

[19] Barbour T, Belcher WJ, Brothers PJ, Rickard CEF, Ware DC. Preparation of group-15 (phosphorous, antimony, and bismuth) complexes of meso-tetrapara-tolylporphyrin (TTP) and X-ray crystal structure of [Sb(TTP) $\left.\left(\mathrm{OCH}\left(\mathrm{CH}_{3}\right)_{2}\right)_{2}\right] \mathrm{Cl}$. Inorg Chem 1992; 31:746-755.

[20] Sayer P, Gouterman M, Connell CR. Metalloid porphyrins and phthalocyanines. Acc Chem Res 1982; 15:73-79.

[21] Cheng PC, Liu IC, Hong TN, Chen JH, Wang SS, Wang SL, Lin JC. Synthesis and characterization of phosphorus complexes of mesotetraphenylporphyrin (tpp), and X-ray crystal structure of $\left[\mathrm{P}(\mathrm{tpp})\left(\mathrm{OCH}\left(\mathrm{CH}_{3}\right)_{2}\right)_{2}\right]\left(^{+}\right) \mathrm{Cl}^{-}$. Polyhedron 1996; 15:2733-2740.

[22] Marrese CA, Carrano CJ. Mechanism of electrochemical reduction of the (5,10,5,20-tetraphenylporphinato)dihydroxophosphorous $(\mathrm{V})$ cation. Inorg Chem 1984, 23:3961-3968.

[23] Akiba Ky, Nadano R, Satoh W, Yamamoto Y, Nagase S, Ou Z, Tan X, Kadish KM. Synthesis, structure, electrochemistry, and spectroelectrochemistry of hypervalent Phosphorus( $(\mathrm{V})$ octaethylporphyrins and theoretical analysis of the nature of the $\mathrm{PO}$ bond in $\mathrm{P}(\mathrm{OEP})\left(\mathrm{CH}_{2} \mathrm{CH}_{3}\right)(\mathrm{O})$. Inorg Chem 2001; 40:5553-5567.

[24] Yamamoto Y, Nadano R, Itagaki M, Akiba Ky. Synthesis and structure of phosphorous $(\mathrm{V})$ octaethylporphyrins that contain a sigma-bonded elementcarbon bond - Characterization of a porphyrin bearing an $\mathrm{R}-\mathrm{P}=\mathrm{O}$ bond and relation of the ruffling of the ruffling of the porphyrin core with the electronegativity of the axial ligands. J Am Chem Soc 1995; 117:8287-8288.

[25] Hudson R, Savoie H, Boyle RW. Lipophilic cationic porphyrins as photodynamic sensitisers-Synthesis and structure-activity relationships. Photodiagn Photodyn Ther 2005; 2:193-196. 
[26] Vaz GMF, Paszko, E, Davies AM, Senge MO. High Content Screening as High Quality Assay for Biological Evaluation of Photosensitizers In Vitro. PLOS One 2013; 8:e70653.

[27] Mitton D, Ackroyd R. Photodynamic therapy in oesophageal carcinoma: an overview. Photochem Photobiol Sci 2004; 3:839-850.

[28] Altorki N, Schwartz GK, Blundell M, Davis BM, Kelsen DP, Albino AP. Characterization of cell lines established from Human gastric esophageal adenocarcinomas - Biological phenotype and invasion potential. Cancer 1993; 72:649-657.

[29] Rockett JC, Larkin K, Darnton SJ, Morris AG, Matthews HR. Five newly established oesophageal carcinoma cell lines: Phenotypic and immunological characterization. Br J Cancer 1997; 75:258-263. 